\section{Students knowledge as a contribution to dengue control programs with a great interest}

\section{Viroj Wiwanitkit ${ }^{1}$}

${ }^{1}$ Department of Laboratory Medicine, Faculty of Medicine, Chulalongkorn University. Bangkok, Thailand.

\section{Carta a respeito do artigo:}

Bezerra JM, Silva JS, Ibiapina SS, Tadei WP, Pinheiro VC. Evaluation of students' knowledge as a contribution to dengue control programs. Cien Saude Colet 2011; 16(11):4367-4373.

\section{Produção científica brasileira indexada no Medline}

Brazilian scientific production indexed on MEDLINE

Javier Sanz-Valero ${ }^{1}$

Luis David Castiel ${ }^{2}$

Carmina Wanden-Berghe ${ }^{3}$

${ }^{1}$ Historia de la Ciencia y Ginecología, Departamento de Salud Pública, Universidad Miguel Hernández. jsanz@umh.es

${ }^{2}$ Escuela Nacional de Salud Pública, Fundación Oswaldo Cruz, Río de Janeiro, Brasil.

${ }^{3}$ Universidad CEU Cardenal Herrera, Elche, España.

\section{Carta a respeito do artigo:}

Luchs A. Profile of Brazilian scientific production on A/H1N1 pandemic influenza. Cien Saude Colet 2012; 17(6):1629-1634.

No interessante artigo bibliométrico referente à produção científica brasileira sobre a pandemia de influenza ${ }^{1}$, foi empregada como campo principal de busca «affiliation», a qual, como mencionada na discussão, assinala a procedência
Sir,

I read the recent publication on students' knowledge as a contribution to dengue control programs with a great interest. Bezerra et al. noted that the students' knowledge in more urban area was better and this could contribute to the dengue control program. Indeed, this can reflect that the health knowledge might be affected by the socioeconomic factors. Whether there is an inequity in knowledge providing between more and less urban areas is a big question. Nevertheless, a big consideration on this report is on the conclusion. It is still doubtful that the relationship to the dengue control program can be concluded or not. Indeed, the knowledge survey might not be sufficient to reach the conclusion. The step-by-step, knowledge-attitudepractice (KAP) has to be followed for summarization on the contribution to the program.

geográfica do primeiro autor (ainda que também possa ser a do autor de correspondência) e, como consequência, alguns estudos pertencentes à produção científica brasileira não seriam recuperados. Mais ainda, quando as redes de pesquisa fazem com que os trabalhos de colaboração internacional sejam cada vez mais frequentes; aumentando, para maior benefício dos autores participantes, o indicador bibliométrico de colaboração (insularity). Surpreende a interrogação a um único campo temático para recuperar os artigos de um determinado país, quando há anos que em estudos similares se tem utilizado de forma sistemática a combinação de vários campos².

Por outro lado, não foi possível reproduzir com exatidão a busca efetuada por Luchs ${ }^{1}$, ao não se encontrar na base de dados Medical Subject Heading (MeSH) da U.S. National Library of Medicine [http://www.ncbi.nlm.nih.gov/mesh] os termos «pandemic flu», «pandemic flu 2009» o «H1N1 2009», e como consequência não se poder utilizá-los como Major Topic: ao se tentar buscar, através de PubMed, o termo «"pandemic flu" [MeSH Major Topic]» aparecem nos resultados a frase «Quoted phrase not found».

Poder-se-ia considerar que a utilização de uma estratégia de busca mais adequada haveria 